\title{
Serum biochemistry, haematological profile and organ proportion of broiler starter chicks fed graded levels of palm oil mill effluent (POME)
}

\author{
Agida, C. A. ${ }^{1 *}$, Amaduruonye, W. ${ }^{2}$, Nsa, E. E. ${ }^{3}$ and Nathaniel, J. ${ }^{2}$ \\ 1'Department of Animal Nutrition and Forage Science, College of Animal Science and Animal Production, Michael \\ Okpara University of Agriculture, Umudike, Umuahia, Abia State, Nigeria. \\ ${ }^{2}$ Department of Animal Breeding and Physiology, College of Animal Science and Animal production, Michael Okpara \\ University of Agriculture, Umudike, Umuahia, Abia State, Nigeria. \\ ${ }^{3}$ Department of Animal Science, Faculty of Agriculture and Resource Management, University of Calabar, Calabar, \\ Cross River State, Nigeria. \\ ${ }^{*}$ Corresponding authors. Email: agidachrisagboje@gmail.com; Tel: +234 (0) 8067929337.
}

Copyright (C) 2020 Agida et al. This article remains permanently open access under the terms of the Creative Commons Attribution License 4.0, which permits unrestricted use, distribution, and reproduction in any medium, provided the original work is properly cited.

Received 22nd October, 2020; Accepted 19th November, 2020

\begin{abstract}
The experimental feeding trial conducted for 28 days was carried out to examine the serum biochemistry and haematological responses, organ proportion of broiler starter chickens fed graded levels of palm oil mill effluent (POME). A total of 240 (two hundred and forty) day old marshal broiler chicks strain were used for the study. The chicks were divided into 5 (five) treatment groups and within each group, replicated 4 (four) times at 12 chicks per replicate, feed and water were given ad libitum. Different graded/replacement levels of POME with maize at diet 1 (control) $(0 \%)$, diet 2 $(6 \%)$, diet $3(12 \%)$, diet $4(18 \%)$ and diet $5(24 \%)$ respectively were investigated to ascertain the health implications in feeding broiler chicks with POME by the blood profile and serum biochemical assessment in the study, using Completely Randomized Design (CRD). Data collected were subjected to Analysis of Variances (ANOVA) using SPSS version 20, results were interpreted using Duncan New Multiple Range Test for means separation. Dietary POME intake affects significantly $(p<0.05)$ serum protein, glucose blood levels, enzymes, cholesterol, triglyceride and haematological profile. Organs proportion like, liver, lungs, kidney, pancreas and large intestine were $(p<0.05)$ affected by dietary treatment. Serum total protein, plasma protein, albumin, globulin, creatinine, urea and alanine amino transferase and white blood cell were significantly decreased $(\mathrm{p}<0.05)$. Glucose, aspartate amino transferase, alkaline phosphatase, pack cell volume, red blood cell, haemoglobin, mean corpuscular haemoglobin, mean corpuscular volume, mean corpuscular haemoglobin concentration, significantly increased $(p<0.05)$. Cholesterol blood levels for diet 5 was higher $(p<0.05)$. Triglyceride blood levels for control diet was higher $(p<0.05)$. Cholesterol and triglyceride blood levels for diet 3 were $(p<0.05)$ lowest. From the results obtained from these findings, POME may have possessed some nutritional values required to improve health and reproductive performance of the broiler chickens as alternative feeds replacement for maize.
\end{abstract}

Keywords: Broiler chicks, haematological profile, palm oil mill effluent, serum biochemistry.

\section{INTRODUCTION}

Palm oil mill effluent (POME) is a good source of raw material for bioconversion through biotechnological processes given it high concentration of carbohydrate, protein, nitrogenous compounds, lipids and minerals, as food, cosmetics and pharmaceuticals, and production of citric acid (Habib et al., 1997; Jamal et al., 2007; Aliyu and
Zahangir, 2012). The production of carotenoid and tocopherols from POME (Wahid et al., 2004). Carotenoid is a provitamin, the Beta-Carotene which is the precursor of vitamin $\mathrm{A}$, whose function in the maintenance of strong, healthy skin and feather growth and as a source of potent antioxidant for removing free radicals in chicks. Conver- 
sion of POME to potential feedstuff involves fermentation (anaerobic, thermophilic and acidophilic), followed by concentration (centrifugation or decantation down to 15 to 20\% dry matter) (Perez, 1997; Chavalparit 2006), also absorption on dry feeds such as cassava roots, dehydrated grass, palm kernel meal, rice bran or by conventional drying methods (Perez, 1997; Chavalparit, 2006). The raw effluent contains 90 to $95 \%$ water, residual oils, soil particles, palm kernel shell, palm kernel fibres, and suspended solids. POME contains a high concentration of chemical oxygen demand (COD) ranging from 45,000 to $65,000 \mathrm{mg} / \mathrm{L}$, biochemical oxygen demand (BOD) ranging from 21,500 to $28,500 \mathrm{mg} / \mathrm{L}$ and high total suspended solids (TSS) ranging from 15,660 to 23,560 $\mathrm{mg} / \mathrm{L}$ (Wong et al., 2009; Chan et al., 2013). Oil and grease content in POME is as high as $4,000 \mathrm{mg} / \mathrm{L}$ with $\mathrm{pH}$ between 3.4 and 4.7 (Bello et al., 2013). Chemical composition of POME has been reported: $72.88 \%$ dry matter, $10.17 \%$ crude protein, $19.20 \%$ ether extract, $8.13 \%$ crude fibre, $6.38 \%$ ash, $56.14 \%$ nitrogen free extract, $3953.0 \mathrm{kcal} / \mathrm{g}$ metabolizable energy, $0.193 \%$ calcium, $0.381 \%$ phosphorus, $0.178 \%$ sodium, $0.372 \%$ potassium, $0.246 \%$ magnesium, $156.570 \mathrm{mg} / \mathrm{kg}$ iron, $26.104 \mathrm{mg} / \mathrm{kg}$ zinc, $3.430 \mathrm{mg} / \mathrm{kg}$ copper and $8.139 \mathrm{mg} / \mathrm{kg}$ manganese (Table 1) (Agida et al., 2019b). Wan Zahari et al. (2009) also gave $91.1 \%$ dry matter, $11.1 \%$ crude protein, $17.0 \%$ crude fibre, $12.0 \%$ ether extract, $9.0 \%$ ash, $50.5 \%$ nitrogen free extract, $0.70 \%$ caicium, $0.50 \%$ phosphorus, and $6.52 \mathrm{MJ} / \mathrm{Kg}$ metabolizable energy. Habib et al. (1997) reported $6.99 \%$ moisture, $12.75 \%$ crude protein, $10.21 \%$ crude lipid, $14.88 \%$ ash, $29.55 \%$ carbohydrate, $26.39 \%$ nitrogen free extract, $0.019 \%$ total carotene, $8951.55 \mu \mathrm{g} / \mathrm{g}$ potassium, $94.57 \mu \mathrm{g} / \mathrm{g}$ sodium, $1650.09 \mu \mathrm{g} / \mathrm{g}$ calcium, $911.95 \mu \mathrm{g} / \mathrm{g}$ magnesium, 14377.38 $\mu \mathrm{g} / \mathrm{g}$ phosphorus, $13.32 \mu \mathrm{g} / \mathrm{g}$ sulphur, $11.08 \mu \mathrm{g} / \mathrm{g}$ iron, $10.76 \mu \mathrm{g} / \mathrm{g}$ copper, $17.58 \mu \mathrm{g} / \mathrm{g}$ zinc and $38.81 \mu \mathrm{g} / \mathrm{g}$ manganese. Increase weight gain and better performance has been reported on broilers and laying chicks fed diets with POME (Agida et al., 2019b; Faradonbeh et al., 2011; Alikwe et al., 2011). Some limiting factors in feeding chicks with POME directly are the low protein and amino acids contents, and the high fibre content (Sinurat et al., 2000).

High cost of livestock feeds and the attendant high cost of poultry products arising from the cost of maize, make protein needs of man unaffordable while reducing expected marginal return to farmers, inadequate supply of feed at the right quality and quantity to the birds as well as lack of knowledge of feeding programmes and poor technological application has kept the production at a subsistent level. Recently, the fear about the future availability of energy feeds for use in the farm animal diets, around the world has been evident of discussion at various meetings, conferences, proceedings, seminars and workshops as revealed by Anigbogu and Adekule-Agbale (2013). Cereals constitute the major energy feedstuff and also make up more than one third of the finished feed for poultry. Maize is an important source of energy in human nutrition and due to its high price; it is becoming more expensive to use at high levels in poultry feeds. A byproduct of interest in palm oil production in term of substituting energy in conventional monogastric diet is palm oil sludge. Processing of palm fruit involves six stages (sterilization, stripping, milling, separation, pressing and clarification). The palm oil sludge is collected at the stage of clarification after the palm oil has been skimmed, what remains is called palm oil mill effluent. Palm oil mill effluent is the final liquid discharge after extracting the oil from the fruit bunch; it contains soil particles, residual oil and suspended solid and represents $0.5 \%$ of fresh fruit and can cause problem to the entire surrounding ecosystem.

In Nigeria over dependence on crude oil has resulted in negligence and poor utilization of the enormous potential benefits inherent in the agro-industrial by-product readily available in the palm mill/processing industries, with POME (palm oil mill effluent) as one of such. POME is a waste product from the palm oil mill processing industries that are little known and used in livestock feeds especially poultry in Nigeria. The local oil palm processing industries in Nigeria has high potentials for the production of highvolume POME required to meet the value added advantages in all round usage as animal feed from agroindustrial by-products. Among rural dwellers in Cross River State, the most common among them in palm oil processing is that method described by Agida et al. (2019a) especially in Ogoja and Boki, in those communities so mention, there are folklore that fowls and most domesticated livestock boost their immunity by feeding on sludge/slurry from POME. Thus, POME that is relatively uneconomical and as a waste agro processed product could be on alternative to maize in broiler chicken diets. Haematological studies are very important in diagnosing the structural and functional status of the animal's body (Elagib et al., 2011). Haematological changes are routinely used to determine various influences of environmental, nutritional and or pathological factors (Graczyk et al., 2003). For proper management of broiler chicken, it is desirable to know the normal physiological values under normal situation. For example, high PCV (\%) and high $\mathrm{Hb}$ ( $\mathrm{g} \%$ ) are indicators of high feed conversion efficiency (Nyaulingo, 2013). The haematological parameters of healthy birds are influenced by many factors which include feed restriction and nutrient conditions (Etim et al., 2014), environmental factors (Vecerek et al., 2002; Graczyk et al., 2003), fasting (Lamosova et al., 2004), nutritional contents (Bashar et al., 2010), water and feed restriction (Iheukwumere and Herbert, 2003; Boostani et al., 2010), age (Talebi et al., 2005), continuous supplementations of vitamin E (Tras et al., 2000), administration of drugs (Squires and Julian, 2001; Suresh et al., 2012), breed (Mushi et al., 1999) and aflatoxin (Oğuz et al., 2000). Thus, the study was conducted to evaluate serum biochemical parameters, haematological profile and organ proportion of broiler starter chicks fed graded levels of palm oil mill effluent. 
Table 1 Mineral and proximate composition of palm oil mill effluent.

\begin{tabular}{lclc}
\hline Minerals & Values & Proximate & Values \\
\hline Sodium \% & 0.178 & Dry matter \% & 66.16 \\
Potassium\% & 0.372 & Ether extract \% & 23.58 \\
Calcium \% & 0.193 & Crude fibre \% & 2.67 \\
Phosphorus \% & 0.381 & Ash \% & 5.89 \\
Magnesium \% & 0.246 & Nitrogen free extract \% & 57.80 \\
Iron $(\mathrm{Mg} / \mathrm{kg})$ & 156.571 & Meabolizadle energy $(\mathrm{kcal} / \mathrm{kg})$ & 4.38 \\
Zinc $(\mathrm{Mg} / \mathrm{kg})$ & 26.662 & Gross energy $(\mathrm{kcal} / \mathrm{kg})$ & 4.80 \\
Copper $(\mathrm{mg} / \mathrm{kg})$ & 3.431 & & \\
Manganese $(\mathrm{mg} / \mathrm{kg})$ & 8.116 & & \\
\hline
\end{tabular}

\section{MATERIALS AND METHODS}

\section{Experimental site and materials collection}

The experiment was carried out at the Poultry Unit, Teaching and Research Farm of Michael Okpara University of Agriculture, Umudike, Umuahia, Abia State. The farm is located within latitude $05^{\circ} 29^{1}$ North and longitude $07^{0} 32^{1}$ East. The farm lies in the altitude of 122 $\mathrm{m}$ and within the rainforest zone of south-east Nigeria, which is bimodal rainfall pattern and total annual rainfall of $2177 \mathrm{~mm}$, maximum ambient temperature ranged of 22 to $36^{\circ} \mathrm{C}$ during the hot dry season of the year (NovemberMarch) and minimum ambient temperature range of 20 to $26^{\circ} \mathrm{C}$ during the cold rainy season (April-October). The relative humidity ranges from 50 to $90 \%$ and is located in warm humid tropics (NRCRI, 2017).

\section{Procurement/processing of POME}

The POME used for the experiment was collected from Ishiborr Community in Ogoja Local Government Council Area of Cross River State, Nigeria, was locally processed based on traditional method of oil palm processing. The POME was packed in a sack bag and allowed to stay for 24 hours to enable water to drain out, leaving the sludge which was later air dried for 21 days Agida et al., (2019a). This was then stored for chemical analysis and feed formulation. The air-dried palm oil effluent was used in formulating the experimental diets.

\section{Processing of palm oil and collection of palm oil mill effluent (POME)}

Collection of POME was from a local/indigenous processing method in Ogoja. Figure 1 show the flow chart of palm oil processing. The palm oil mill effluent was then packed in a bag to drain out the water leaving behind the slurry/sludge as described by Agida et al. (2019a) in the flow chart.

\section{Experiment diets}

Five experimental diets (D1, D2, D3, D4 and D5) were formulated with POME included at $0,6,12,18$ and $24 \%$ respectively to meet the nutrient requirements of the broiler starter. The nutrient compositions of the experimental diets are shown in Table 2.

\section{Experimental layout/experimental animals and management}

The experimental design was completely randomized and the birds were reared on deep litter using wood shavings. Two hundred and forty (240) day old chicks (Marshal breed/strain) were allotted randomly to five experimental diets and replicated 4 times with 12 birds per replicate. The experiment lasted for 4 weeks. The birds were placed on the experimental starter diets for four weeks, from the day one. Feed and water were given ad-libitum, electric bulb, stoves and lantern were used in providing illumination and heat for the brooding stage. Routine drugs and vaccine administration and hygienic conditions, were followed and maintained.

\section{Sample collection/laboratory analysis}

At the end of the 28 days feeding trial, four birds per replicate (12 birds/treatment) were sampled and blood samples collected via wing veins using sterile $21 G \times 1 \frac{1}{2}$ $(0.8 \times 40 \mathrm{~mm})$ needles and syringes into bottles containing anticoagulant (ethylene diamine tetra acetic acid; EDTA) for haematology as described by Lamb (1981). Pack cell volume was determined using micro-haematocrit as described by Coles (1986). Kachmar (1970) method for haemoglobin concentration $(\mathrm{Hb})$ of the blood samples were analyzed using cyano-methaemoglobin. Schalm et al. (1975) methods for red blood cell (RBC) and white blood cell (WBC) counts were determined using haemocytometer. Blood samples for serum biochemistry were collected into $10 \mathrm{ml}$ test tubes without anticoagulant. 


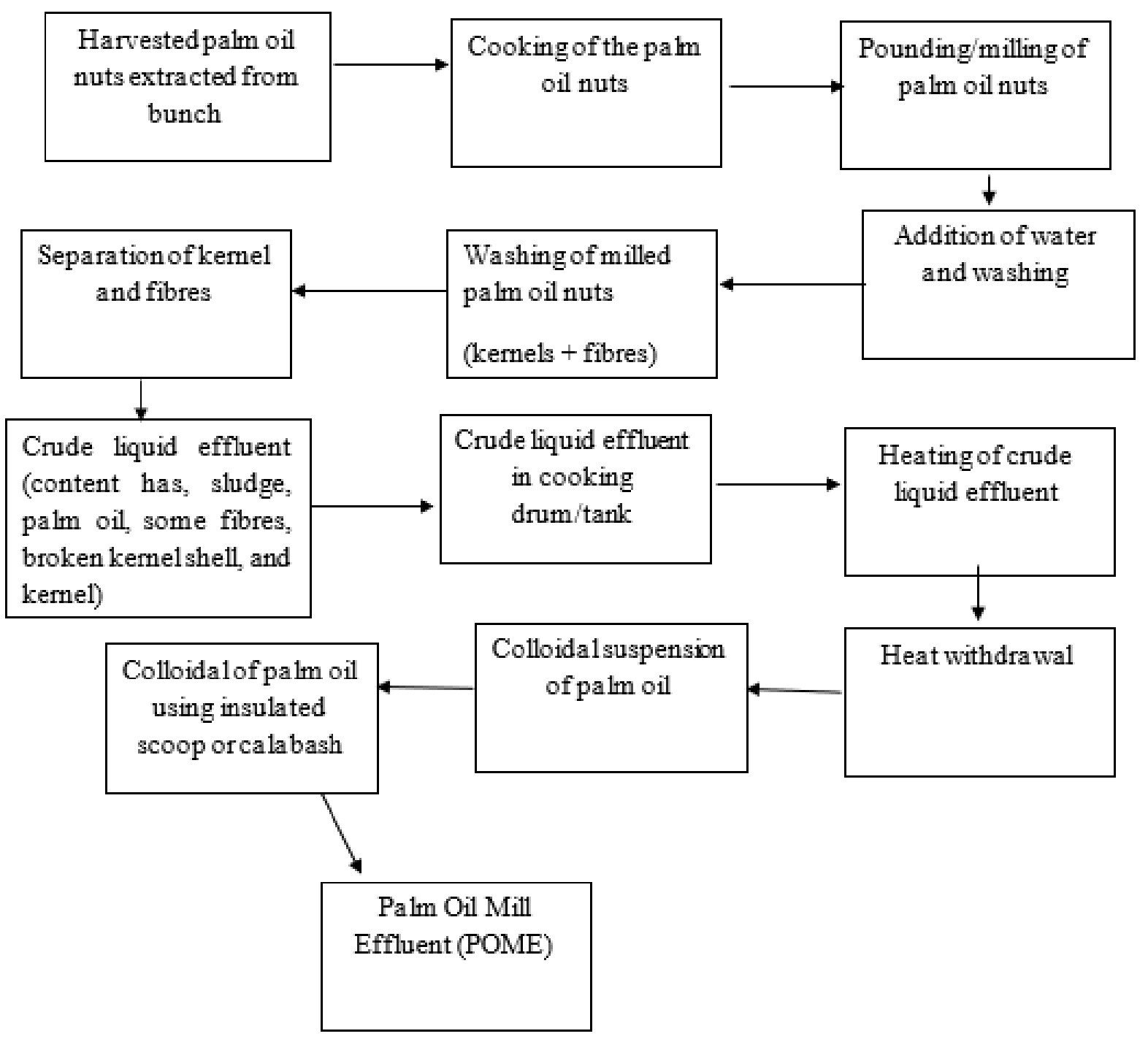

Figure 1. Flow chat of processing of palm oil.

Serum was obtained by allowing the blood sampled to clot at room temperature for 30 minutes, after which it was centrifuged for ten minutes at 3,000 revolutions per minute using a table centrifuge. The clear serum supernatant was then carefully aspirated with syringe and needle and stored in a clean sample bottle.

Decanted sera from the coagulated blood samples were saved by freezing at $-180 \mathrm{c}$ until analyzed for serum biochemistry according to Feng et al. (1973). Alanine Aminotransferase (ALT) and Aspartate Amino Transferase (AST) were determined by the Reintman-Frankel colorimedric method for the in-vitro determination of ALT and AST in serum or plasma using a Quimica Clinica Aplicada (QCA) test kit according to Reitman and Frankel (1975). For the in vitro determination of alkaline phosphate in serum or plasma using phenolphthalein monophosphate method as described by Klein et al. (1960) and Babson et al. (1966). Total protein was determined in-vitro according to Lubran (1978). The in-vitro determination of albumin in serum was done using modified Jaffe method (Blass et al., 1974). Serum cholesterol and glucose for in-vitro determination was analysed using enzymatic colorimetric method (Allain et al., 1974). The data collected were subjected to one-way analysis of variance for haematological variables serum biochemistry.

\section{Data analysis}

Data collected were subjected to one-way analysis of variance (ANOVA) as described by Steel and Torrie (1980). Where significant differences were found, the means were separated and compared using Duncan's New Multiple Range Test (DNMRT) (Duncan, 1980). Statistical computations were done using IBM SPSS (20th edition). 
Table 2 Composition of experimental diets.

\begin{tabular}{lccccc}
\hline \multirow{2}{*}{ Parameters } & \multicolumn{5}{c}{ Diets/Ingredient (\%) } \\
\cline { 2 - 5 } & D1 (0.0) & D2 (6.0) & D3 (12.0) & D4 (18.0) & D5 (24.0) \\
\hline Maize & 57.9 & 51.9 & 45.9 & 39.9 & 33.9 \\
Soya bean meal & 35.6 & 35.6 & 35.6 & 35.6 & 3.56 \\
POME & - & 6.0 & 12.0 & 18.0 & 24.0 \\
Fish meal & 3.00 & 3.00 & 3.00 & 3.00 & 3.00 \\
Bone meal & 1.70 & 1.70 & 1.70 & 1.70 & 1.70 \\
Oyster shell & 1.00 & 1.00 & 1.00 & 1.00 & 1.00 \\
Vitamin/mineral premix & 0.25 & 0.25 & 0.25 & 0.25 & 0.25 \\
Methionine & 0.15 & 0.15 & 0.15 & 0.15 & 0.15 \\
Lysine & 0.20 & 0.20 & 0.20 & 0.20 & 0.20 \\
Salt & 0.20 & 0.20 & 0.20 & 0.20 & 0.20 \\
Total (kg) & 100 & 100 & 100 & 100 & 100 \\
Crude Protein (\%) & 23.031 & 23.151 & 23.271 & 23.391 & 23.510 \\
ME (kcal/kg) & 2955.6 & 3142.8 & 3330.0 & 3517.2 & 3704.4 \\
Ether Extract (\%) & 3.46 & 3.84 & 4.55 & 4.58 & 4.93 \\
Crude Fibre (\%) & 2.92 & 4.02 & 5.18 & 6.20 & 7.23 \\
\hline
\end{tabular}

Vitamin-mineral premix supplied (per kg of diet); Vitamin $A, 2500 l u$, Vitamin $D_{3}$ 2600lu, Riboflavin $9.0 \mathrm{~g}$, Biotin $0.25 \mathrm{mg}$, Vitamin $\mathrm{B}_{2} 2.5 \mathrm{mg}$, Vitamin $\mathrm{B}_{12}$ $8.0 \mathrm{mg}$, Nicotinic acid $8.0 \mathrm{mg}$ Iron $3.50 \mathrm{mg}$, Manganese $10 \mathrm{mg}$, Zinc $4.5 \mathrm{mg}$, Cobalt $0.02 \mathrm{mg}$, Selenium $0.01 \mathrm{mg}$.

\section{RESULTS}

Serum total protein, plasma protein, albumin, globulin, creatinine and blood urea differed $(p<0.05)$ significantly as presented in Table 3 . Serum total protein showed significant $(p<0.05)$ differences among treatment levels. Broiler chicks fed control diet had highest serum total protein, which decreased as the inclusion levels of palm oil mill effluent (POME) increased. Plasma protein showed significant $(p<0.05)$ differences among treatment levels. Broiler chicks on control diet had highest plasma protein concentration which decreased in the order of POME inclusion. Albumin concentration showed significant $(p<0.05)$ differences among treatment, the highest albumin concentration observed with broiler chicks fed control diet and it decreased as the level of POME inclusion increased. Mean albumin concentration observed with broiler chicks fed experimental diets, were below normal standard range $(2.0$ to $3.5 \mathrm{~g} / \mathrm{dl})$ as reported by Ross et al. (1978). Globulin concentration showed significant $(p<0.05)$ differences among treatment, the highest globulin concentration recorded among broiler chicks fed control diet, and it gradually decreased with increased POME inclusion. Creatinine content of broiler chicks fed experimental diet differed $(p<0.05)$ among treatment levels. Broiler chicks fed control diet had the highest creatinine concentration and decreased gradually with increased POME inclusion levels. Urea blood levels were significant $(p<0.05)$ among treatment. The blood urea blood content showed highest value for chicks fed control diet, and this decreased with increased level of POME inclusion. The urea blood levels obtained with broiler chicks fed diet 2, 3, 4 and 5, were between standard normal range (2 to $8 \mathrm{mg} / \mathrm{dl}$ ) with that of healthy broiler chicks reported by Ross et al. (1978) for biochemical indices.

Table 4 present data on glucose levels, enzymes, cholesterol and triglycerides. All parameters differed $(p<0.05)$ significantly among treatment. Glucose levels in broiler starter chicks fed experimental diet were significantly $(p<0.05)$ influenced by dietary treatment with POME. Chicks fed diet showed increased glucose levels/content with increased POME inclusion. Highest blood glucose obtained for chicks fed diet 5, while the lowest blood glucose obtained with chicks fed control diet, normal range for glucose levels in broiler chicks as reported by Ross et al. (1978) is 125 to $200 \mathrm{~g} / \mathrm{dll}$, this showed that only diet 5 had glucose level above the normal range. Aspartate amino transferase (AST) were significantly $(p<0.05)$ increased with and increased inclusion of POME, with the highest AST on broiler chicks fed diet 5, the lowest AST were obtained for chicks fed control diet, all values for Aspartate Amino Transferase were between that reported by Ross et al. (1978) for normal range of broiler chicks. Alanine amino transferase (ALT) decreased significantly $(p<0.05)$ as POME inclusion levels increased. Chicks fed control diet showed highest ALT content, while the lowest were obtained for chicks fed diet 5 , chicks fed diet 3 and 4 were numerically similar, all values obtained for Alanine amino transferase were below that of the normal range reported by Ross et al. (1978). Alkaline phosphatase (ALP) increased significantly $(p<0.05)$ among treatment levels, with increased POME inclusion. The highest ALP values were observed with chicks fed diet 5 , while the lowest were seen in chicks fed control diet. Cholesterol levels differed significantly $(p<0.05)$ among treatments. 
Table 3. Data on serum protein.

\begin{tabular}{|c|c|c|c|c|c|c|}
\hline \multirow{2}{*}{ Parameters } & \multicolumn{5}{|c|}{ Percentage replacement with palm oil mill effluent } & \multirow{2}{*}{ SEM } \\
\hline & D1 (0.0) & D2 (6.0) & D3 (12.0) & D4 (18.0) & D5 (24.0) & \\
\hline Serum Total Protein ( $\mathrm{g} / \mathrm{dl})$ & $3.93^{a}$ & $3.62^{b}$ & $3.33^{c}$ & $3.32^{c}$ & $2.80^{\mathrm{d}}$ & 0.10 \\
\hline Plasma Protein (g/dl) & $4.20^{\mathrm{a}}$ & $4.16^{a}$ & $3.65^{b}$ & $3.54^{b}$ & $3.15^{c}$ & 0.21 \\
\hline Albumin $(\mathrm{g} / \mathrm{dl})$ & $1.85^{\mathrm{a}}$ & $1.40^{\mathrm{b}}$ & $1.35^{\mathrm{c}}$ & $1.34^{c}$ & $1.30^{\mathrm{d}}$ & 0.05 \\
\hline Globulin (g/dl) & $2.28^{a}$ & $2.13^{b}$ & $1.97^{\mathrm{c}}$ & $1.92^{c}$ & $1.54^{d}$ & 0.06 \\
\hline Creatinine $(\mathrm{mg} / \mathrm{dl})$ & $0.58^{a}$ & $0.33^{b}$ & $0.31^{b}$ & $0.22^{b}$ & $0.18^{c}$ & 0.04 \\
\hline Urea (mg/dl) & $15.96^{\mathrm{a}}$ & $7.18^{b}$ & $4.78^{c}$ & $2.38^{d}$ & $0.78^{e}$ & 1.43 \\
\hline
\end{tabular}

Values on the same row with the same letter(s) superscripts are not significantly different $(P<0.05)$. Values on the same row with the same letter(s) superscripts are significantly different $(P<0.05)$, SEM: Standard error of mean.

Table 4. Data on glucose level, enzymes, cholesterol and triglyceride.

\begin{tabular}{|c|c|c|c|c|c|c|}
\hline \multirow{2}{*}{ Parameters } & \multicolumn{5}{|c|}{ Percentage replacement with palm oil mill effluent } & \multirow{2}{*}{ SEM } \\
\hline & D1 (0.0) & D2 (6.0) & D3 (12.0) & D4 (18.0) & D5 (24.0) & \\
\hline Glucose (g/dl) & $162.33^{e}$ & $182.67^{d}$ & $187.00^{c}$ & $197.00^{b}$ & $247.67^{a}$ & 7.69 \\
\hline Aspartate Amino Transferase $(\mu \mathrm{l})$ & $95.00^{e}$ & $108.00^{d}$ & $113.00^{c}$ & $131.00^{\mathrm{b}}$ & $139.00^{\mathrm{a}}$ & 4.26 \\
\hline Alanine Amino Transferase $(\mu \mathrm{l})$ & $7.33^{a}$ & $6.00^{\mathrm{ab}}$ & $5.00^{b}$ & $5.00^{\mathrm{b}}$ & $4.00^{\mathrm{C}}$ & 0.38 \\
\hline Alkaline Phosphatase $(\mu \mathrm{l})$ & $248.67^{e}$ & $260.81^{d}$ & $276.31^{c}$ & $326.32^{b}$ & $407.25^{a}$ & 15.53 \\
\hline Cholesterol (mg/dl) & $86.95^{d}$ & $95.95^{c}$ & $83.76^{e}$ & $100.58^{b}$ & $106.58^{a}$ & 2.25 \\
\hline Triglyceride (mg/dl) & $53.29^{a}$ & $20.06^{d}$ & $19.12^{\mathrm{e}}$ & $24.12^{\mathrm{c}}$ & $51.28^{\mathrm{b}}$ & 4.11 \\
\hline
\end{tabular}

Values on the same row with the same letter(s) superscripts are not significantly different $(p<0.05)$. Values on the same row with the same letter(s) superscripts are significantly different $(p<0.05)$, SEM: Standard error of mean.

Table 5. Data on haematological profile.

\begin{tabular}{|c|c|c|c|c|c|c|}
\hline \multirow{2}{*}{ Parameters } & \multicolumn{5}{|c|}{ Percentage replaced with palm oil mill effluent } & \multirow{2}{*}{ SEM } \\
\hline & D1 $(0.0)$ & D2 (6.0) & D3 (12.0) & D4 (18.0) & D5 (24.0) & \\
\hline Pack Cell Volume (\%) & $24.33^{e}$ & $27.50^{d}$ & $30.97^{c}$ & $31.50^{\mathrm{b}}$ & $32.00^{\mathrm{a}}$ & 0.78 \\
\hline Red Blood Cell $\left(\times 10^{6 /} \mu \mathrm{l}\right)$ & $2.56^{c}$ & $2.69^{b}$ & $2.70^{\mathrm{b}}$ & $2.78^{\mathrm{a}}$ & $2.96^{\mathrm{a}}$ & 0.04 \\
\hline White Blood Cell $\left(\times 10^{6 /} \mu \mathrm{l}\right)$ & $35.50^{\mathrm{a}}$ & $26.05^{b}$ & $14.45^{\mathrm{c}}$ & $10.15^{d}$ & $9.90^{\mathrm{e}}$ & 2.68 \\
\hline Haemoglobin $(\mathrm{g} / \mathrm{dl})$ & $6.65^{d}$ & $8.41^{\mathrm{c}}$ & $8.41^{\mathrm{c}}$ & $8.79^{b}$ & $9.73^{a}$ & 0.27 \\
\hline $\mathrm{MCH}(\mathrm{Pg})$ & $25.94^{\mathrm{e}}$ & $28.41^{d}$ & $31.27^{c}$ & $32.65^{b}$ & $32.80^{a}$ & 0.71 \\
\hline MCV (fl) & $92.70^{\mathrm{e}}$ & $102.22^{a}$ & $104.03^{c}$ & $106.42^{b}$ & $118.52^{\mathrm{a}}$ & 2.00 \\
\hline $\mathrm{MCHC}(\mathrm{g} / \mathrm{dl})$ & $26.71^{\mathrm{e}}$ & $27.10^{d}$ & $27.64^{c}$ & $30.58^{b}$ & $31.39^{a}$ & 0.51 \\
\hline
\end{tabular}

Values on the same row followed by the same letter(s) superscripts are not significantly different $(p<0.05)$. Values on the same row with different letter(s) superscripts are significantly different $(\mathrm{p}<0.05)$. MCH: Mean Corpuscular Haemoglobin, MCV: Mean Corpuscular Volume, MCHC: Mean Corpuscular Haemoglobin Concentration, SEM: Standard error of mean.

Chicks fed diet 5 had highest blood cholesterol value, followed by chicks fed diet 4,2 and 1 (control), while the lowest blood cholesterol levels were obtained with birds fed diet 3 . The results for the cholesterol levels were between normal standard range 52 to $148 \mathrm{mg} / \mathrm{dl}$ as reported by Ross et al. (1978) and Onibi et al. (2011). Triglyceride blood levels differed $(p<0.05)$ significantly among treatments. Broiler chicks on diet 1 (control) had highest blood triglyceride levels, followed by chicks fed diet 5,4 and 2, while chicks fed diet 3 had lowest blood triglyceride levels.
Data on haematological profile as presented on Table 5 were significantly $(p<0.05)$ influenced by dietary treatments. Pack Cell Volume (PCV), red blood cell (RBC) and haemoglobin differed significantly $(p<0.05)$ among treatments, both increased with increased levels of POME. Red blood cell $(\mathrm{RBC})$ differed significantly $(\mathrm{p}<0.05)$ among treatments. White blood cell (WBC) were significant $(p<0.05)$ among treatments and it decreased as the POME inclusion level increased. Mean corpuscular haemoglobin, mean corpuscular volume, and mean corpuscular haemoglobin concentration were found $(p<0.05)$ to have 
Table 6. Data on internal organ profile.

\begin{tabular}{lcccccc}
\hline \multirow{2}{*}{ Parameters } & \multicolumn{4}{c}{ Percentage replaced with palm oil mill effluent } & \multirow{2}{*}{ SEM } \\
\cline { 2 - 5 } & D1 (0.0) & D2 (6.0) & D3 (12.0) & D4 (18.0) & D5 (24.0) & \\
\hline Heart & 0.48 & 0.44 & 0.49 & 0.58 & 0.60 & 0.03 \\
Kidney & $0.96^{\mathrm{a}}$ & $0.88^{\mathrm{ab}}$ & $0.72^{\mathrm{abc}}$ & $0.58^{\mathrm{bc}}$ & $0.52^{\mathrm{c}}$ & 0.06 \\
Lungs & $0.48^{\mathrm{ab}}$ & $0.54^{\mathrm{ab}}$ & $0.55^{\mathrm{ab}}$ & $0.58^{\mathrm{a}}$ & $0.34^{\mathrm{b}}$ & 0.03 \\
Liver & $3.40^{\mathrm{a}}$ & $2.92^{\mathrm{b}}$ & $2.60^{\mathrm{bc}}$ & $2.33^{\mathrm{c}}$ & $2.24^{\mathrm{c}}$ & 0.13 \\
Pancreas & $0.43^{\mathrm{ab}}$ & $0.54^{\mathrm{a}}$ & $0.50^{\mathrm{a}}$ & $0.50^{\mathrm{a}}$ & $0.34^{\mathrm{b}}$ & 0.02 \\
Gizzard & 2.58 & 2.70 & 2.32 & 2.57 & 2.65 & 0.09 \\
Small Intestine & 5.26 & 5.40 & 4.95 & 5.13 & 4.98 & 0.12 \\
Large Intestine & $1.05^{\mathrm{b}}$ & $1.05^{\mathrm{b}}$ & $1.71^{\mathrm{a}}$ & $0.91^{\mathrm{b}}$ & $0.86^{\mathrm{b}}$ & 0.09 \\
Proventriculus & 0.62 & 0.79 & 0.55 & 0.75 & 0.60 & 0.04 \\
Crop & 0.62 & 0.93 & 0.66 & 0.66 & 0.60 & 0.04 \\
\hline
\end{tabular}

Values on the same row with the same letter(s) superscripts are not significantly different $(p<0.05)$. Values on the same row with the same letter(s) superscripts are significantly different $(p<0.05)$, SEM: Standard error of mean.

increased with increased POME.

Organ proportion were significantly $(p<0.05)$ influenced by treatment levels as presented on Table 6. Heart proportion for chicks fed experimental diets were not influenced $(p>0.05)$ by dietary treatment levels. Organ proportion on the kidney were influenced $(p<0.05)$ by treatment levels. Highest kidney proportion were obtained for chicks fed control diets, which decreased as POME inclusion levels increased. Lungs proportion differed $(p<0.05)$ among treatments. The highest among chicks fed diets were obtained in diet 4 and lowest in diet 5 , chicks fed control diet, were relative statistically among chicks fed diet 2 and 3 . Liver proportion differed $(p<0.05)$ among chicks, with the highest liver proportion found on control diet, which decreased with increased POME inclusion. Pancreas proportion on broiler chicks fed diets were highest $(p<0.05)$ among broilers chicks fed diet 2, 3 and 4 , while chicks on control diet were relative statistically among treatments, with the lowest pancreas proportion among chicks fed diet 5 . Gizzard and small intestine proportion were not influenced $(p<0.05)$ with dietary treatments. Proportion on large intestine were highest $(p<0.05)$ among broiler chicks fed diet 3 , while chicks fed diet 1 (control), 2, 4 and 5 were relatively statistically with the lowest on diet 5. Proportion on proventriculus and crop were not significant $(p<0.05)$ among treatments.

\section{DISCUSION}

On the feeding of starter broiler chicks with POME, serum biochemical, haematological parameters and organ proportions differed $(p<0.05)$ among the treatment diets. Serum biochemical parameters results were shown to have had direct gradient effects on the chicks. Blood biochemical analysis is widely used to assist the diagnosis and characterization of diseases in most animal species, but it is seldom used in avian species. However, it is an important tool, as some metabolic disorders are difficult to detect only by clinical signs (Andreasen et al., 1996). It can also assist the monitoring of poultry health, the diagnosis and treatment of diseases, and to assess their health status (Schmidt et al., 2007). Serum total protein, plasma protein, albumin, globulin, creatinine and urea all decreased with increased inclusion of POME, which is relative to direct effect and response of the chicks on treated diets. According to Harr et al. (2002), serum total protein values of broilers tend to be lower than those of mammals, ranging from 25.00 to $45.00 \mathrm{~g} / \mathrm{L}$. Among numerous factors that influence the concentration of serum proteins, age plays an important role in the physiology. Generally, concentration of proteins is significantly lower in young animals than in adults (Kaneto et al., 1997). Urea and creatinine are nitrogenous end products of metabolism. Urea is the primary metabolite derived from dietary protein and tissue protein turnover. Creatinine is the product of muscle creatinine metabolism. The blood urea nitrogen is roughly one-half $(0.47)$ of the blood urea. The normal range of urea nitrogen in blood or serum is 5 to $20 \mathrm{mg} / \mathrm{dl}$ or 1.8 to $7.1 \mathrm{mmol}$ urea per litre. The normal serum creatinine varies with the subject body muscle mass and with the technique used to measure it. The normal range of serum creatinine is 0.6 to $1.2 \mathrm{mg} / \mathrm{dl}$, or 53 to $106 \mu \mathrm{mol} / \mathrm{l}$ by the kinetic or enzymatic method, and 0.8 to $1.5 \mathrm{mg} / \mathrm{dl}$, or 70 to $133 \mu \mathrm{mol} / \mathrm{l}$ by other older manual Jaffe reaction.

The ultimate source of energy for most cells is glucose. Level of glucose found from the blood serum of broiler chicks fed experimental diets had increased proportionately, thus gave an indication that palm oil mill effluent (POME) contained simple carbohydrate source readily available for the animal as compare to maize. These has also followed with increased glucose base enzyme alkaline phosphatase. Amino acids base enzymes aspartate amino transferase and alanine amino transferase were also affected by dietary treatments. Aspartate 
amino transferase, a four carbon atom amino basedenzyme required for the synthesis of aspartic acids, a nonessential amino acids were found to have increased with increased POME, an indication of increased utilization of aspartate by the chicks. Alanine amino transferase, a three carbon atom amino based-enzyme were found to decreased with increased POME inclusion. This could have indicated that the aspartate amino transferase might have supported the synthesis of aspartic acids from the increased glucose supplied from POME inclusion levels. While alanine amino transferase might have favoured the production of alanine based essential amino acids from the reverse as to a decreased POME supply in the diet. Cholesterol blood levels for broiler chicks were between normal standard range as reported by Onibi et al. (2011) and Ross et al. (1978), it is an indication that POME showed no detrimental effects to excess fat accumulation around muscles and liver. The triglyceride for dietary levels were lower than that of the control diet. There was no case of hypercholesterolmanic tendency as observed among experimental animals.

Pack cell volume (PCV), red blood cell (RBC) and haemoglobin were found to increase with increased POME inclusion. Findings from other authors suggested that since PCV is derived from red blood cell (RBC), increase or decrease in the number of RBC has direct effect on PCV and haemoglobin which conform with the results from the findings. Results presented from these studies showed an increased in PCV, having direct effects with corresponding increase in RBC and haemoglobin. The PCV values obtained from the experimental diets were within the physiological range of 22 to 35,26 to 33 and 24.87 to $32.75 \%$ as stated respectively by Jain (1986), Godwin et al. (1992) and Onyishi et al. (2017), the PCV for that reported by Talebi et al. (2005) for four different strains of broiler (Arian, Arbore-Acres, Ross and Cobb) showed only broiler chicks fed control and diet 2 falling below the range 29.85 to $32.80 \%$ at day 28 . Value for RBC showed only broiler chicks fed diet 5 slightly above range 2.38 to 2.79 $\left(\times 10^{6} / \mu \mathrm{l}\right)$ as stated by Talebi et al. (2005). For that of Onyishi et al. (2017), range 2.23 to $2.70\left(\times 10^{12} / \mathrm{l}\right)$ had diet 5 and 4 slightly above stated range. Haemoglobin values were all below range 14.57 to $15.00 \mathrm{~g} / \mathrm{dl}$ and 12.60 to $13.42 \mathrm{~g} / \mathrm{dl}$ reported respectively by Onyishi et al. (2017) and Talebi et al. (2005). Normal red blood cell, pack cell volume and haemoglobin production requires diets containing protein, iron, copper, vitamin $\mathrm{B}_{2}, \mathrm{~B}_{6}, \mathrm{~B}_{12}$ and folic acids (Nyaulingo, 2013). Nyaulingo (2013) further stated that high RBC, PCV and haemoglobin are indicators of high feed conversion efficiency. Low PCV is an indication of anemia or polycythemic disorder. This could be an indication that POME must have contained trace amount of iron, copper, and the vitamin B complex, responsible for the production of the blood cells. White blood cell (WBC), were found to have decreased with increased POME inclusion. Talebi et al. (2005) and Onyishi et al. (2017) stated normal standard range for broilers as 21.87 to $22.74\left(\times 10^{3} / \mu \mathrm{l}\right)$ and 8.96 to 11.04 $(\times 10 \% / \mu \mathrm{l})$. Reports from various authors on laboratory analysis for haematological profiles explained that high WBC above normal range for animals, is an indication that the animal maybe diseased or undergoing stress. Decreased WBC with increased POME inclusion as presented in this study might be an indication of prophylactic active ingredients found in POME. Since white blood cells in the avian species, in general, serve to phagocytic function similar to their mammalian counterparts (Campbell and Coles, 1986). The mean corpuscular haemoglobin $(\mathrm{MCH})$ is the concentration of haemoglobin in a given volume of packed red blood cells. The value for $\mathrm{MCH}$ were below normal range 54.38 to $56.14 \mathrm{Pg}$ and 46.8 to $56.14 \mathrm{Pg}$ reported by Onyishi et al. (2017) and Talebi et al. (2005), respectively. This might be an indication of dietary treatments. Mean corpuscular volume (MCV) is the expression of the average volume of individual red blood cells. MCV were within normal range 92.42 to $148.88(\mathrm{fl})$ reported by Onyishi et al. (2017), except for that of the control diet all others MCV were within range 113.8 to 129.41 (fl) stated by Talebi et al. (2005). The mean corpuscular haemoglobin concentration (MCHC) measures the concentration of haemoglobin in a given volume of packed red blood cells. Values for $\mathrm{MCHC}$ were below normal range 49.08 to $60.21(\mathrm{~g} / \mathrm{l})$ and 34.6 to 43.93(\%) reported by Onyishi et al. (2017) and Talebi et al. (2005), respectively. Information indicate that haematological values of avian species are also significantly influenced by poultry diseases including fowl typhoid (Kokosarov and Todorova, 1987), mycoplasmosis (Branton et al., 1997; Burnham et al., 2003), infectious bursal disease (Panigrahy et al., 1986; Juranova et al., 2001), Newcastle disease (Galindo-Muniz et al., 2001) and toxoplasmosis (Kaneto et al., 1997). They have been no standard for haematological profiling for poultry as regards reference nutritional requirements of broiler chickens world-wide.

Internal organ proportion were significantly affected on kidney, lungs, liver, pancreas and the large intestine. Those organs so affected by dietary treatments levels, are major organs were hormonal and enzymatic secretions for the breakdown, digestion and assimilation of food takes place are kidney, liver and the pancreas. The liver and the kidney size decreased with increased POME. Reports from several authors stated that high fatty feeds caused adipose accumulation around the liver and the muscles tissues, increasing the weight of the liver.

\section{Conclusion}

The present study indicates that, serum protein, glucose level, enzymes, cholesterol, triglyceride and haematological profile were all affected by dietary treatment with POME. Serum protein and alanine amino phosphatase decreased with increased POME, glucose, 
aspartate amino transferase, and alkaline phosphatase had increased. Cholesterol decreased at diet 3 and increased at diet 5 , while triglyceride also decreased at diet 3 and increased at the control.

Haematological profile for PCV, RBC, haemoglobin, $\mathrm{MCH}, \mathrm{MCV}$, and $\mathrm{MCHC}$ had increased with increased POME dietary inclusion, that of WBC had increased. Internal organ was only affected on lungs, liver, kidney, pancreas and the large intestine. From the results obtained from this study, POME may have possessed some nutritional values required to improve health and reproductive performance of the broiler chickens as alternative feeds replacement for maize.

\section{CONFLICT OF INTEREST}

The authors declare that they have no conflict of interest.

\section{REFERENCES}

Agida, C. A., Nathaniel, J., Ukoha, O. a., \& Ukachukwu, S. N. (2019a). Haematological and serological indices of broiler finisher chickens fed diets with palm oil mill effluent as replacement for maize. Nigerian Agricultural Journal, 50(2), 38-44.

Agida, C. A., Ukoha, O. A., Ukachukwu, S. N., \& Amaefule, K. U. (2019b). Proximate, mineral analysis and growth performance of broiler chickens fed diets containing palm oil mill effluent. Nigerian Agricultural Journal, 50(2), 81-86.

Aliyu, S., \& Zahangir, A. (2012). Palm oil mill effluent: a waste or a raw material? Journal of Applied Sciences Research, 8(1), 466-473.

Allain, C. C., Poon, L. S., Chan, C. S., Richmond, W., \& Fu, P. C. (1974). Enzymatic determination of total cholesterol. Clinical Chemistry, 20(4), 470-475.

Andreasen, J. R., Andreasen, C.B., Sonn, A. B., \& Robeson, D. C. (1996). The effects of hemolysis on serum chemistry measurements in poultry. Avian Pathology, 25(3), 519-536.

Anigbogu, N. M., \& Adekule-Agbale, O.I.L. (2013). Performance and economic benefits of Zymomonas mobilis or in combination with Asparagus oryzae treated sawdust fed goats as feed. Nigerian Agricultural Journal, 44(1), 189-198.

Babson, A. L., Greesley, S. J., Coleman, C. M., \& Philips, G. E. (1966). Phenolphthalein monophosphate as a substrate for serum alkaline phosphate. Clinical Chemistry, 12(18), 482490.

Bashar, Y. A., Tukur, H. M., Sekoni, A. A., \& Hassan, W. A. (2010) Nutrient retention and haematological indices of broiler starters fed lablab seed meal as the source of protein. Nigerian Journal of Basic and Applied Science, 18(2), 285-291.

Bello, M. M., Nourouzi, M. M., Abdullah, L. C., Choong, T. S., Koay, Y. S., \& Keshani, S. (2013). POME is treated for removal of color from biologically treated POME in fixed bed column: applying wavelet neural network (WNN). Journal of Hazardous Materials, 262, 106-113.

Blass, K. G., Thibert, R. J., \& Lam, L. K. (1974). A study of the mechanism of the Jaffe reaction. Journal of Clinical Biochemistry, 12, 336-343.

Boostani, A., Ashayerizadeh, A., Mahmoodian, F. H. R., \& Kamalzadeh, A. (2010). Comparison of the effects of several feed restriction periods to control ascites on performance, carcass characteristics and hematological indices of broiler chickens. Revista Brasileira de Ciência Avícola ,12(3), 170177.

Branton, S. L., May, J. D., Lott, B. D., \& Maslin, W. R. (1997). Various blood parameters in commercial hens acutely and chronically infected with Mycoplasma gallisepticum and Mycoplasma synoviae. Avian Diseases, 41, 540-547.

Burnham, M. R., Peebles, E. D., Branton, S. L., Jones, M. S., \& Gerard, P. D. (2003). Effects of F-strain Mycoplasma gallisepticum inoculation at twelve weeks of age on the blood characteristics of commercial egg laying hens. Poultry science, 82(9), 1397-1402.

Campbell, T. W., \& Coles, E. H. (1986). Avian clinical pathology. In: Coles, E. H. (ed.). Veterinary Clinical Pathology, 4th edition Saunders Co., Philadelphia, the USA, Pp. 279-300.

Chan, Y. J., Mei-Fong, C., \& Chung-Lim, L. (3013). Optimization of palm oil mill effluent treatment in an integrated anaerobicaerobic bioreactor. Sustainable Environment Resources, 23(3), 153-170.

Chavalparit, O. (2006). Clean technology for the crude palm oil industry in Thailand. PhD Thesis, Wageningen University.

Coles, E. H. (1986). Veterinary clinical pathology, 4th edition. W. B Saunders co., Philadelphia. Duncan, O. B. (1980). Multiple range and multiple F- Tests. Biometrics, 11, 1-42.

Elagib, H. A. \& Ahmed, A. D. (2011). Comparative study on haematological values of blood of indigenous chickens in Sudan. Asian Journal of Poultry Science, 5(1), 41-45.

Etim, N. N., Williams, M. E., Akpabio, U., \& Offiong, E. E. A. (2014). Haematological parameters and factors affecting their values. Agricultural Science, 2(1), 37-47.

Faradonbeh, O. P., Bagheri, H., \& Soleimani, R. (2011). Efficacy of palm oil sludge commercial chicken performance traits. Animal Veterinary Science, 1(12), 66-69.

Feng, H., Pi, C., Wang, R., \& Chen L. (1973). Use of ferric ammonium sulphate in serum cholesterol determination. Clinical Chemistry, 19(1), 121-122.

Galindo-Muniz, F., Calderon, N. L., Charles, M. N., Tellez, I. G., \& Fortoul, T. I. (2001). Haematological and histological findings in experimental Newcastle disease. Acta Veterinaria Brno, 70(2), 185-189.

Godwin, M. A., \& Davis, J. F. \& Brown, J. (1992). Pack cell volume reference intervals to aid in the diagnosis of anemia and polycythemia in young broiler chickens. Avian Disease, 36(2), 440-443.

Graczyk, S., Pliszczak-Król, A., Kotoński, B., Wilczek, J., \& Chmielak, Z. (2003). Examinations of hematological and metabolic changes mechanisms of acute stress in turkeys. Electronic Journal of Polish Agricultural Universitie (Veterinary Medicine), 6(1), 8p.

Habib, M. A. B., Yusoff, F. M., Phang, S. M., Ang, K. J., \& Mohamed, S. (1997). Nutritional value of chironomid larvae grown in palm oil mill effluent and algae culture. Aquaculture, 158(1-2), 95-105.

Harr, K. E. (2002). Clinical chemistry of companion avian species: A review. Veterinary Clinical Pathology, 31(3):140151.

Iheukwumere, F. C., \& Herbert, U. (2003). Physiological responses of broiler chickens to quantitative water restrictions: Haematology and serum biochemistry. International Journal of Poultry Science, 2(2), 117-119.

Jain, N. C. (1986). Schalm's veterinary haematology, 4th edition. Lea and Febiger, USA.

Jamal, P., Alam, M. Z., \& Mohamad, A. (2007). Microbial 
bioconversion of palm oil mill effluent to citric acid with optimum process conditions. In: Ibrahim, F., Abu Osman, N. A., Usman, J., \& Kadri, N. A. (eds.). Biomed 06, IFMBE Proceedings, 15, 483-487.

Juranova, R., Nga, N. T., Kulikova, L., \& Jurajda, V. (2001). Pathogenicity of Czech isolates of infectious bursal disease virus. Acta Veterinaria Brno, 70(4), 425-431.

Kachmar, J. F. (1970). Determination of haemoglobin by cyanomethaemoglobin procedure. In: Fundamentals of Clinical Chemistry, Philadelphia: WB Saunders Company, Pp. 268-269.

Kaneto, C. N., Costa, A. J., Paulillo, A. C., Moraes, F. R., Murakami, T. O., \& Meireles, M. V. (1997). Experimental toxoplasmosis in broiler chicks. Veterinary Parasitology, 69(34), 203-210.

klein, B., Read, P. A., \& Babson, A. L. (1960). Rapid method for the quantitative determination of serum alkaline phosphatase. Clinical Chemistry, 6(3), 269-275.

Kokosarov, T., \& Todorova, T. (1987). Changes in the iron content, erythrocytes and hemoglobin in the blood of poultry with acute experimental fowl typhoid. Veterinarno-meditsinski Nauki, 24(5), 70-74.

Lamb, G. N. (1981). Manual of veterinary laboratory techniques. CIBA-Geirgy, Kenya. Pp. 92-109. Lubran, M. M. (1978). The measurement of total serum proteins by the Biuret method. Annals of Clinical Laboratory Science, 8(2), 106-110.

Lamošová, D., Máčajová, M., \& Zeman, M. (2004). Effects of short-term fasting on selected physiological functions in adult male and female Japanese quail. Acta Veterinaria Brno, 73(1), 9-16.

Mushi, E. Z., Binta, M. G., Chabo, R. G., \& Ndebele, R. T. (1999). Haematological studies on apparently healthy Tswana indigenous chicken (Gallus domesticus) around Gaborone, Botswana. (NFFI) News Letter, 9, 83-88.

NRCRI (2017). Agro-Meteorologic Unit. National Root Crop Research Institute, Umudike, Umuahia, Abia State, Nigeria.

Nyaulingo, J. M. (2013). Effect of different management systems on haematological parameters in layer chickens. A dissertation submitted in partial fulfillment of the requirements for the degree of Master of Science in Comparative Animal Physiology of Sokoine University of Agriculture, Morogoro, Tanzania.

Oğuz, H., Keçeci, T., Birdane, Y. O., Önder, F., \& Kurtoğlu, V. (2000). Effect of clinoptilolite on serum biochemical and haematological characters of broiler chickens during aflatoxicosis. Research in Veterinary Science, 69(1), 89-93.

Onibi, G. E., Bobadoye, A. O., \& Folorunso, O. R. (2011). Haematological indices, serum cholesterol and meat quality of broiler chickens fed diets with palm oil sludge substituting maize. Agriculture and Biology Journal of North America, 2(3), 552-558.

Onyishi, G. C., Oguine, C. C., Nwani, S. I., Aguzie, I. O., \& Nwani, C. D. (2017). Haematological parameters dynamics of developing Gallus gallus domesticus. Animal research international, 14(2), 2769-2776.

Panigrahy, B., Rowe, L. D., \& Corrier, D. E. (1986). Haematological values and changes in blood chemistry in chickens with infectious bursal disease. Research in Veterinary Science, 40(1), 86-88.

Pérez, R. (1997). Feeding pigs in the tropics. FAO Animal Production and Health Paper-132.
Reitman, S., \& Frankel, S. (1975). A colourimetric method for determination of serum glutamic oxaloacetic and glutamic pyrivic transaminases. American Journal of Clinical Pathology, 28, 56-62.

Ross, J. G., Christie, G., Halliday, W. G., \& Jones, R. M. (1978). Haematological and blood chemistry" comparison values" for clinical pathology in poultry. The Veterinary Record, 102(2):2931.

Schalm, O. W., Jain, N. C., \& Caroll, E. J. (1975). Veterinary Hematology, 3rd edition. Lea and Fabriger, Philadelphia. Pp. 19-25.

Schmidt, E. M. S., Locatelli-Dittrich, R., Santin, E., \& Paulillo, A. C. (2007). Patologia clínica em aves de produção - uma ferramenta para monitorar a sanidade avícola - revisão. Archives of Veterinary Science, 12(3), 9-20.

Sinurat, A. P., Purwadaria, T., Ketaren, P. P., Zainuddin, D., \& Kompiang, I. P. (2000). Utilization of palm oil sludge in poultry diet. 1. Dried palm oil sludge and its fermented product in broilerâ€ $€^{\mathrm{TM}}$ s diet. Jurnal IImu Ternak dan Veteriner, 5(2), 107 112.

Squires, E. J., \& Julian, R. J. (2001). The effect of dietary chloride and bicarbonate on blood $\mathrm{pH}$, haematological variables, pulmonary hypertension and ascites in broiler chickens. British Poultry Science, 42(2), 207-212.

Steel, R. G. D., \& Torrie, J. H. (1980). Principle and Procedures of Statistics. A biochemical Approaches, 2nd edition. McGrawHill book co. New York, USA.

Suresh, K. V., Sarath, C. G., Ramesh, J., Vairamuthu, S., Thejomoorthy, P., \& Hariharan, P. (2012). Effect of enrofloxacin administration on haematological profile in broiler chicken - A safety pharmacology study. Indian Journal of Field Veterinarians, 8(2), 20-24.

Talebi, A., Asri-Rezaei, S., Rozeh-Chai, R., \& Sahraei, R. (2005). Comparative studies on haematological values of broiler strains (Ross, Cobb, Arbor-acres and Arian). International Journal of Poultry Science, 4(8), 573-579.

Tras, B., Inal, F., Bas, A. L., Altunok, V., Elmas, M., \& Yazar, E. (2000). Effects of continuous supplementations of ascorbic acid, aspirin, vitamin $\mathrm{E}$ and selenium on some haematological parameters and serum superoxide dismutase level in broiler chickens. British Poultry Science, 41(5), 664-666.

Vecerek, V., Strakova, E., Suchy, P., \& Voslarova, E. (2002). Influence of high environmental temperature on production and haematological and biochemical indexes in broiler chickens. Czech Journal of Animal Science, 47(5), 176-182.

Wahid, M. D., Abdullah, S. N. A., \& Heson, I. E. (2004). Oil palmachievements and potential: 2004 new directions for a diverse planet. Proceedings of the 4th International Crop Science Congress (26th Sep-1st Oct). Brisbane, Australia.

Wan Zahari, M., Wong, H. K., \& Hussain, S. A. S. (2009). Utilization of animal feedstuffs in Malaysia. In: Animal Feedstuffs in Malaysia-Issues, Strategies and Opportunities. Academy of Sciences, Malaysia, Pp. 1-10.

Wong, F. P., Nandong, J., \& Samyudia, Y. (2009). Optimised treatment of palm oil mill effluent. International Journal of Environment and Waste Management, 3(3-4), 265-277. 